\title{
第而部 研究委員会・研究会の動向
}

\section{II 特別研究会・アドホック研究会・ミニ研究会の動向}

ミニ研究会／記念基金助成研究テーマ

「若手溶接技術者・研究者のグローバルネットワークの形成」

川上 博士 *, 佐藤 裕 ${ }^{* *}$

Report on Activities of the Committee to Form "Global Network of Young

Engineers and Researchers in Welding and Joining Fields" at 2009

by KAWAKAMI Hiroshi* and SATO Yutaka**

キーワード : 若手技術者・研究者, 溶接・接合, グロ 一バルネットワーク, 国際化, アジア

\section{1 はじめに}

平成16（2004）年度より，溶接学会記念基金助成活動 の一環として，「若手溶接技術者・研究者のグローバル ネットワークの形成」委員会が発足した。本委員会は主 にAWF（アジア溶接連盟）会議期間中に開催されるセミ ナーおよびシンポジウムへの発表者派遣活動を行ってい る。さらに，溶接学会と韓国溶接・接合学会共催による 若手研究者によるシンポジウムも毎年開催している。こ のように本委員会は, 積極的に現地研究者ならびに AWF 加盟国研究者との交流を行っている。ここでは平成 21 （2009）年度の活動を報告する。

\section{2 第12回AWF会議併催シンボジウム}

$\mathrm{AWF}$ 会議は早いもので 12 回目の開催を数えるに至っ た.今回の会議は IIW 年次大会にあわせて開催され, 会 場も大会会場の一室が使用された。

日時：2009年 7 月13日（月）14:30

場所 : シンガポール・Grand Copthone Waterfront

参加人数 : 約 30 名

下記に示すように 6 件の発表が行われた。国別内訳は,

中国 2 件，フィリピン（アンチー・ペン氏（シンガポー ル）代読） 1 件，日本 3 件であった.

1. "High Speed Double-electrode gas metal arc welding"

Prof. Chuansong Wu (Shanghai Jaodong University)

2. "A new method for quantitative evaluation of opening performance of welding consumable"

Prof. Zhuonxin Li (Beijing University of Science

原稿受付 平成 22 年 4 月 15 日

*正 員 三重大学 Member, Mie University

**正 員 東北大学 Member, Tohoku University

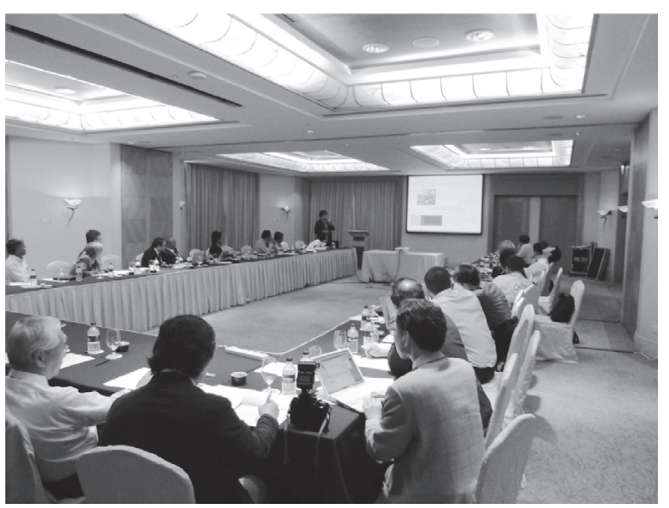

図 1 AWF シンポジウム

and Technology)

3. "i-MOS Progress Situation in Phillipine Welding Society" on behalf of PWS" .

Mr. Ang Chee Pheng (SWS, President)

4. "Direct observation of microstructure change under the thermal cycle of weld"

寺崎秀紀（大阪大学接合科学研究所）

5. “Development of Ultra-High-Speed GTA Welding

Process using Pulse-heated Hot-wire”

山本元道 (広島大学)

6. "Effect of Coarse Carbide Particles on SR Embrittlement in HAZ of 2 1/4Cr-1Mo Steel”

川上 博士 (三重大学)

\section{3 第5回日韓若手研究者シンポジウム}

韓国溶接・接合協会と共催の第 5 回日韓若手研究者シ ンポジウムが韓国・済州島にて開催された。

日時：2009年11月26日（木）13:00〜

場所：韓国済州島・済州国際会議場

参加人数 : 約 50 名

日韓合計で10件の講演が行われた（下記）。溶接力学, 溶接治金からアーク物理など溶接工学に関する幅広い講 演発表があり，活発な討論が交わされた。

1. "Effect of welding variables on crack arrest tough- 
ness of thick steel plates"

Mr. Kang Mook Ryu (POSCO)

2. Bead Formation and Wire Temperature Distribution during Ultra-high-speed GTA Welding Using Pulse-heated Hot-wire” 山本元道 (広島大学)

3. “Design of Metal Cored Wire for Erosion Resistant Overlay Welding" Dr. Jun Ki Kim (KITECH)

4. "Wetting properties between silver-copper-titanium braze alloy and hexagonal boron nitride" 瀬知啓久（鹿児島県工業技術センター）

5. “A study on welding deformation of thin plate block in PCTC"

Dr. Sung Ku Kang (STX Offshore \& Shipbuilding)

6. "Characteristics of electrially conductive adhesives filled with silver-coated copper” 西川 宏 (大阪大学接合科学研究所)

7. "Ultrasonic welding technology for solar thermal collector"

Dr. Sung Wook Kim (RIST)
8. "Mechanism of intragranular ferrite formation in heat-affected zone of titanium killed-steel” 寺崎秀紀（大阪大学接合科学研究所）

9. "Characteristics of spark ignition for micro-/nanoscale joining"

Prof. Hae Woon Choi (Keimyung Univ.)

10. "Weld formation mechanism during friction stir spot welding of $6061 \mathrm{Al}$ ”

佐藤 裕 (東北大学)

\section{4 おわりに}

2010年度は，溶接学会春季全国大会にあわせて第13回 $\mathrm{AWF}$ 会議が東京にて開催された。また併催シンポジウム も韓国溶接・接合学会との第 6 回日韓若手シンポジウム とコラボレーションする形式で開催された。

\section{謝辞}

本活動は, 溶接学会フェローの皆様を始め, 会員各位 のご理解とご支援によって活動が可能となっておりま す。この場をお借りして，皆様に御礼申し上げます。 